\title{
A New Efficient Route to Tolterodine
}

\author{
Carlo Botteghi, ${ }^{*} \uparrow$ Tatiana Corrias, ${ }^{\ddagger}$ Mauro Marchetti, ${ }^{\ddagger}$ Stefano Paganelli, ${ }^{\dagger}$ and Oreste Piccolo ${ }^{\S}$ \\ Dipartimento di Chimica - Università Ca’ Foscari di Venezia, Calle Larga S. Marta 2137, I-30123 Venezia, Italy, \\ Istituto di Chimica Biomolecolare - CNR, traversa La Crucca 3, Loc. Baldinca - Li Punti, I-07040 Sassari, Italy, and \\ Studio di Consulenza Scientifica, via Bornò 5, Sirtori (LC), Italy
}

\begin{abstract}
:
Tolterodine, an important urological drug, can be conveniently prepared starting from 1-[2-hydroxy-5-methyl)phenyl]-1phenylethylene, accessible in high yield by alumina-promoted ortho alkenylation of $p$-cresol with phenylacetylene. The hydroformylation of this olefin, catalyzed by rhodium complexes both in homogeneous or in aqueous biphasic system, affords the desired linear aldehyde in about $80-90 \%$ yield. The reductive amination of this aldehyde, in the presence of $\mathrm{HN}$ $\left({ }^{i} \mathrm{Pr}\right)_{2}$ and $\mathrm{Pd} / \mathrm{C}(5 \%)$ as the catalytic precursor at $4 \mathrm{~atm} \mathrm{H}_{2}$ and $48{ }^{\circ} \mathrm{C}$, produces directly tolterodine in more than $90 \%$ yield. Some experiments of enantioselective hydroformylation of 1-[2-hydroxy-5-methyl)phenyl]-1-phenylethylene catalyzed by $\operatorname{Rh}(\mathrm{CO})_{2}$ acac/ $(S, R)$-Binaphos and other enantiopure ferrocenyldiphosphines afforded only low yields of the expected chiral aldehyde; unfortunately, the achieved ee did not exceed $8 \%$.
\end{abstract}

\section{Introduction}

Urinary incontinence is a condition affecting more than $10 \%$ of the adult population and can represent an embarassing problem for many people, negatively influencing their normal way of life. ${ }^{1}$ As the mean age of the worldwide population begins to rise, one can speculate that such a pathology is fated to increase its relevance as a health problem.

In the search for new drugs with improved side effect profiles to treat an overactive bladder, a family of phenylpropylamines as muscarinic receptor antagonists has been investigated, and very recently, $(+)(R)$-tolterodine 1 (Figure 1) (brand names Detrol or Detrusitol) was launched and marketed worldwide with success as the $(R, R)$-tartaric acid salt. ${ }^{1,2}$ The annual consumption increment is estimated about $20 \%$. The bulk production in 15 most industrialized countries in the world in 1999 was $450 \mathrm{~kg}$. $^{3}$

The original synthetic approaches to this molecule ${ }^{4}$ are characterized by numerous steps (more than six), some of

* To whom correspondence should be addressed. Telephone: +39-0412348515. Fax: +39-041-2348517. E-mail: botteghi@unive.it.

$\dagger$ Università Ca’ Foscari di Venezia.

* Istituto per l’Applicazione per le Tecniche Chimiche Avanzate ai Problemi Agrobiologici.

\$ Studio di Consulenza Scientifica

(1) Drugs Future 1997, 22 (7), 733.

(2) Daily Drug News, Com (Daily Essentials), 1997-1999 (21 November, 1997; 11 March, 1998; 30 March, 1998; 3 December, 1998; 30 August, 1999).

(3) Based on Index of Drug Chemicals in the Ten More Industrialized Countries; IMS Health: London, U.K., 2000.

(4) Jonsson, N. A.; Sparf, B. A.; Mikiver, L.; Moses, P.; Nilvebrant, L.; Glas, G. (Pharmacia \& Upjohn Co.). EP 0325571, 1989.

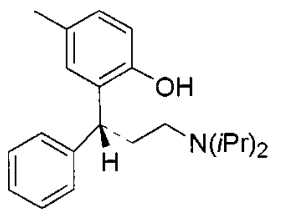

$(+)(\mathrm{R})$-Tolterodine

(1)

\section{Figure 1.}

which involve the use of toxic or hazardous reagents and solvents, give only fair yields, or both. A classical resolution via the formation of diastereomeric salts with $(R, R)$-tartaric acid is used to achieve the enantiomerically pure molecule; even if the racemization and the recycle of the unwanted $(S)$-enantiomer does not seem particularly difficult to accomplish, it requires additional costs; hence, it is strongly desirable to eliminate it from the productive process. Also, a recently published asymmetric approach ${ }^{5}$ to $\mathbf{1}$ appears quite costly for industrial application.

Recently, a more efficient synthesis involving a lower step number has been claimed in a U.S. patent to obtain $(R, S)$ tolterodine; this is characterized by the preparation of the hemiacetalic compound 3,6-dihydro-6-methyl-4-phenyl-2Hbenzopyran-2-ol (3a) as a key intermediate. ${ }^{6}$

Another more recent patent ${ }^{7}$ reported a multistep synthetic route to $\mathbf{3 a}$ enriched in the $(R)$-enantiomer. This fact documents the remarkable interest in finding asymmetric processes leading to $(+)(R)$-tolterodine suitable for industrial application.

Before these patents were published, we presented at international symposia ${ }^{8-10}$ a synthetic approach to hemiacetal 3a following a quite different strategy, namely the regioselective rhodium-carbonyl complex-catalyzed hydroformylation of 1-[(2-hydroxy-5-methyl)]-1-phenylethene (2a). We based this approach on previous experiences ${ }^{11-14}$ in the production of several compounds endowed with interesting

(5) Andersson, P. G.; Schink, H. E.; Osterlund, K. J. Org. Chem. 1998, 63, 8067.

(6) Gage, J. R.; Cabaj, J. E. (Pharmacia \& Upjohn Co.). U.S. Patent 5,922,914, 1999.

(7) Andersson, P. G.; Hedberg, Ch. (Pharmacia \& Upjohn Co.). WO 0149649, 2001.

(8) Marchetti, M.; Sechi, B.; Botteghi, C.; Paganelli, S. 11th International Symposium on Homogeneous Catalysis (ISHC 11); St. Andrews, Scotland, 12-17 July, 1998; p 50.

(9) Botteghi, C.; Marchetti, M.; Paganelli, S.; Piccolo, O.; Sechi, B. 10th Symposium on Organometallic Chemistry Directed Towards Organic Synthesis (OMCOS 10); Versailles, France, 18-22 July, 1999.

(10) Botteghi, C.; Marchetti, M.; Paganelli, S.; Piccolo, O. Eur. J. Pharm. Sci. 1998, 6 (Suppl. 1), S38.

(11) Botteghi, C.; Cazzolato, L.; Marchetti, M.; Paganelli, S. J. Org. Chem. 1995, 60,6612 .

Vol. 6, No. 4, 2002 / Organic Process Research \& Development

379 


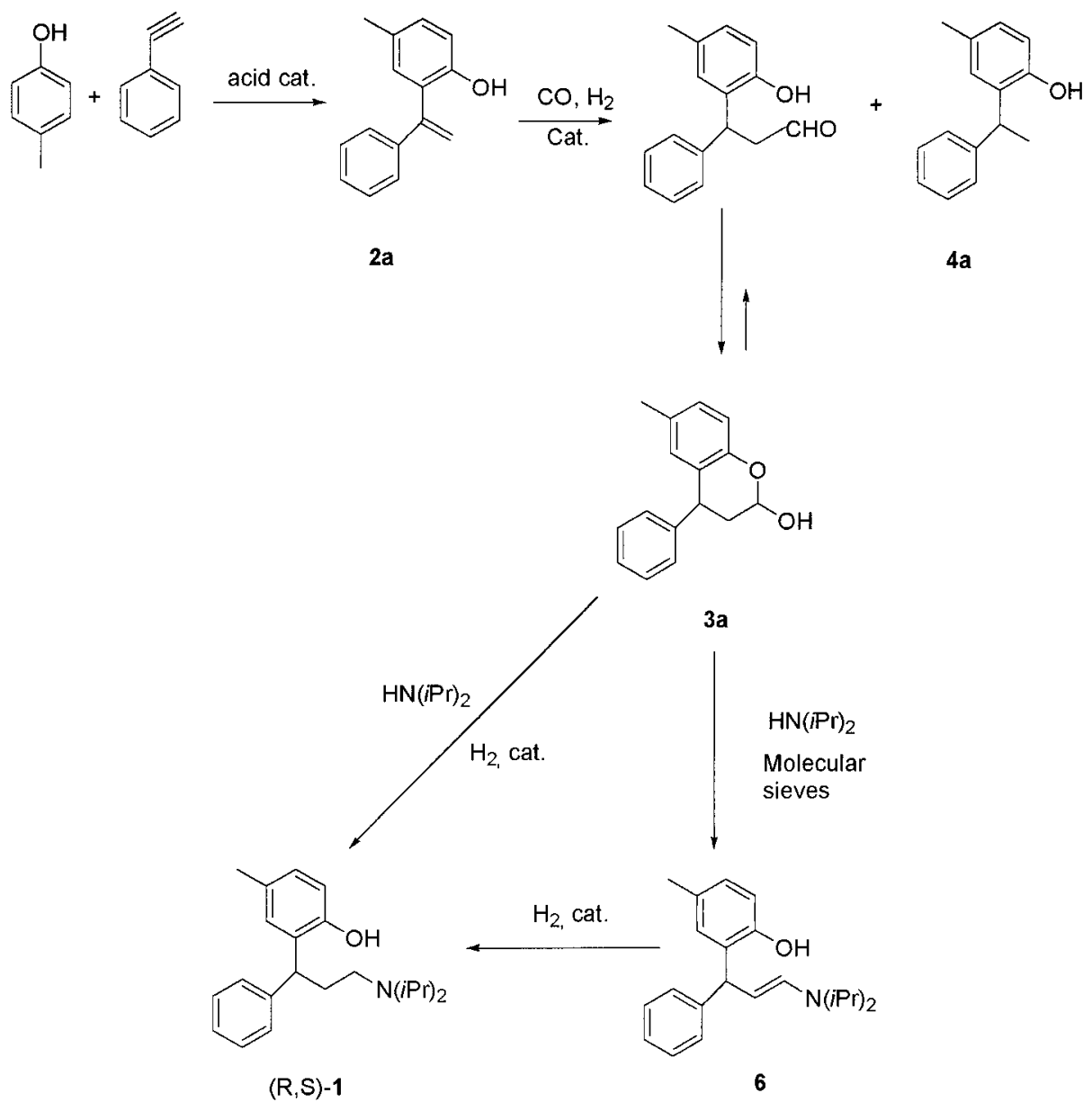

therapeutic activity and containing a 3,3-diarylpropyl- or a 4,4-diarylbutylamine moiety. The idea was to use a synthetic scheme involving catalytic processes with high atom utilization and low salt waste. Indeed, the synthetic route outlined in the patent ${ }^{6}$ is afflicted by a serious drawback, namely the use of DIBAL as the reduction agent, which works in stoichiometric amount with respect to the lactone at low temperature; in addition, it is sensitive to air and moisture.

Furthermore, our synthetic approach, involving the hydroformylation process could be developed in an enantioselective way to produce the key intermediate, hemiacetal $\mathbf{3 a}$, enriched in the desired diastereomer.

\section{Results and Discussion}

The synthetic route to $(R, S)$-tolterodine proposed by us is depicted in Scheme 1.

This short route not only could offer better overall yields and significant improvement in terms of cost reduction, but could also, in principle, permit the formation of a nonracemic chiral center by using rhodium complexes modified with

(12) Botteghi, C.; Marchetti, M.; Paganelli, S. In New Opportunities in Hydroformylation: Selected Syntheses of Intermediates and Fine Chemicals: Beller, M., Bolm, C., Eds.; Transition Metals for Organic Synthesis, Vol. 1; Wiley-VCH: Weinheim, 1998; pp 25-48.

(13) Botteghi, C.; Paganelli, S.; Marchetti, M.; Pannocchia, P. J. Mol. Catal. A: Chem. 1999, 143, 233.

(14) Botteghi, C.; Marchetti, M.; Paganelli, S.; Persi-Paoli, F. Tetrahedron 2001 $57,1631$. enantiomerically pure ligands as catalysts in the hydroformylation step.

The olefinic substrate $\mathbf{2 a}$ to be subjected to the oxo reaction was prepared by ortho alkenylation of $p$-cresol with phenylacetylene, both easily available in the industrial market, according to an experimental procedure described by Sartori et al. ${ }^{15}$ and suitably modified by us. In fact, while the zeolite catalysts employed by these authors, in our hands, did not give the expected selectivity, much better results were obtained using acidic $\mathrm{Al}_{2} \mathrm{O}_{3}$ activated by calcination at 500 ${ }^{\circ} \mathrm{C}$ for $5 \mathrm{~h}$; almost complete chemoselectivity and yields up to $90 \%$ were achieved. Even if the alumina was used in a large amount (47 wt \% with respect to $p$-cresol), this does not represent a serious drawback, owing to its low cost and the possibility to recover and to reactivate it.

The hydroformylation of olefin $\mathbf{2} \mathbf{a}$ to the corresponding linear aldehyde, mostly in the hemiacetalic form $\mathbf{3 a}$, is conveniently carried out either in the biphasic water/toluene system or in organic solvent as, for instance, toluene, in the presence of an appropriate catalytic precursor (see Table 1).

The results obtained in the aqueous biphasic hydroformylation are particularly attractive in the perspective of a semiindustrial application due to the use of an environmentally benign solvent and to the easy separation of the products and nearly quantitative recovery of the expensive rhodium

(15) Sartori, G.; Bigi, F.; Pastorio, A.; Porta, C.; Arienti, A.; Maggi, R.; Moretti, N.; Gnappi, G. Tetrahedron Lett. 1995, 36, 9177. 
Table 1. Rhodium-catalyzed hydroformylation of olefin $2 \mathrm{a}^{a}$

\begin{tabular}{|c|c|c|c|c|c|}
\hline entry & catalytic system & $t(\mathrm{~h})$ & $\begin{array}{l}\text { conv. } \\
(\%)^{b}\end{array}$ & $\begin{array}{c}\text { aldehyde } \\
\text { yield } \\
(\%)^{b}\end{array}$ & $\begin{array}{l}\text { hydrog. } \\
\text { product } \\
(\%)^{b}\end{array}$ \\
\hline $1^{c}$ & {$[\mathrm{Rh}(\mathrm{COD}) \mathrm{Cl}]_{2}$} & 72 & 96.0 & 94.4 & 1.6 \\
\hline $2^{c, d}$ & $\mathrm{HRh}(\mathrm{CO})\left(\mathrm{PPh}_{3}\right)_{3}$ & 48 & 32.3 & 27.1 & 5.4 \\
\hline $3^{c}$ & $\mathrm{HRh}(\mathrm{CO})\left(\mathrm{PPh}_{3}\right)_{3}$ & 48 & 95.2 & 91.6 & 3.6 \\
\hline $4^{c}$ & $\mathrm{Rh}(\mathrm{CO})_{2} \mathrm{acac} / \mathrm{PPh}_{3}$ & 72 & 51.3 & 42.6 & 8.7 \\
\hline $5^{c}$ & $\mathrm{Rh}(\mathrm{CO})_{2} \mathrm{acac} / \mathrm{DPPB}$ & 72 & 83.0 & 74.5 & 8.5 \\
\hline $6^{c}$ & $\mathrm{Rh}(\mathrm{CO})_{2}$ acac/Xantphos & 24 & 10.3 & 6.0 & 4.3 \\
\hline $7^{c}$ & $\mathrm{Rh}(\mathrm{CO})_{2} \mathrm{acac} / \mathrm{Xantphos}$ & 72 & 90.3 & 83.5 & 6.8 \\
\hline $8^{c, e}$ & $\mathrm{Rh}(\mathrm{CO})_{2}$ acac/Xantphos & 72 & 26.2 & 7.9 & 18.3 \\
\hline $9^{f}$ & {$[\mathrm{Rh}(\mathrm{COD}) \mathrm{Cl}]_{2} / \mathrm{TPPTS}$} & 48 & 99.1 & 99.1 & - \\
\hline $10^{f}$ & {$[\mathrm{Rh}(\mathrm{COD}) \mathrm{Cl}]_{2} / \mathrm{TPPTS}$} & 24 & 80.0 & 80.0 & - \\
\hline $11^{f}$ & {$[\mathrm{Rh}(\mathrm{COD}) \mathrm{Cl}]_{2} / \mathrm{Xantphos}\left(\mathrm{SO}_{3} \mathrm{Na}\right)_{2}{ }^{g}$} & 24 & 37.7 & 33.9 & 3.8 \\
\hline \multicolumn{6}{|c|}{ 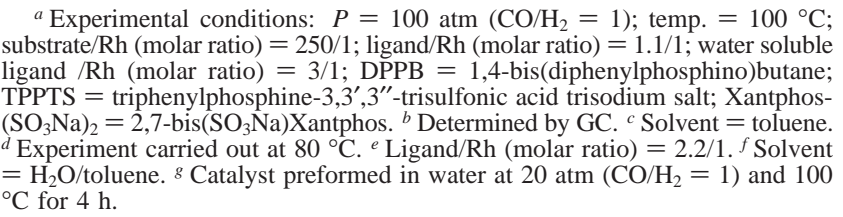 } \\
\hline
\end{tabular}

catalyst; as a matter of fact, we observed, after five recycles of the catalytic solution, a very small efficiency loss $(<5 \%)$. Generally, the only byproduct is compound 4a derived from the olefinic double bond hydrogenation; sometimes we noticed that this compound was the main product when commercial catalytic precursors such as $\mathrm{HRh}(\mathrm{CO})\left(\mathrm{PPh}_{3}\right)_{3}$ and $[\mathrm{Rh}(\mathrm{COD}) \mathrm{Cl}]_{2}$ were employed. When these rhodium complexes are carefully prepared and purified according to wellknown procedures, ${ }^{16,17}$ the chemoselectivity of the oxo reaction is fairly good.

The data reported in Table 1 also show the effect of the phosphine ligands on the reaction; contrary to the results usually observed in the hydroformylation catalyzed by rhodium/phospine complexes, ${ }^{18}$ in several cases we noticed a detrimental influence of the ligand on both reaction rate and chemoselectivity (entries 2,4-8); when this catalytic process was carried out in the more economically convenient and environmentally friendly aqueous biphasic system catalyzed by $[\mathrm{Rh}(\mathrm{COD}) \mathrm{Cl}]_{2} / \mathrm{TPPTS}$, we obtained a good reaction rate and an almost quantitative chemoselectivity (entries 9 and 10). ${ }^{19}$ When Xantphos $\left(\mathrm{SO}_{3} \mathrm{Na}\right)_{2}$ was used as the hydrosoluble ligand, both the reaction rate and the chemoselectivity of the process remarkably decreased (entry 11; see also Figure 2).

Some experiments to prepare $(R, S)$-tolterodine by reductive amination of the hemiacetal 3a in the presence of $\mathrm{PtO}_{2}$ as the catalyst and diisopropylamine at 76 atm of $\mathrm{H}_{2}$ and $120^{\circ} \mathrm{C}$ for $24 \mathrm{~h}$, following a well-described procedure ${ }^{20}$ that demonstrated good success in our previous works, ${ }^{11,12}$ gave unsatisfactory results in this case. However, the catalytic reduction of the corresponding enamine $\mathbf{6}$, prepared by treatment with diisopropylamine in the presence of molecular sieves, afforded the target compound in an efficient way:

(16) Ahmad, N.; Levison, J. J.; Robinson, S. D.; Uttley, M. F. Inorg. Synth. 1974, 15, 45.

(17) Chatt, J.; Venanzi, L. M. J. Chem. Soc. 1957, 4735.

(18) Botteghi, C.; Ganzerla, R.; Lenarda, M.; Moretti, G. J. Mol. Catal. 1987, 40, 129 and references therein.

(19) Paganelli, S.; Zanchet, M.; Marchetti, M.; Mangano, G. J. Mol. Catal. A: Chem. 2000, 157, 1 and references therein.

(20) Jachimowicz, F.; Raksi, J. J. Org. Chem. 1982, 47, 445.<smiles></smiles><smiles>CC1(C)c2cc(O[Na])cc(-c3ccccc3)c2Oc2c(-c3ccccc3)cc(OS(=O)(=O)O[Na])cc21</smiles>

Xantphos $\left(\mathrm{SO}_{3} \mathrm{Na}\right)_{2}$

$83 \%$ yield of tolterodine was obtained after $24 \mathrm{~h}$ at $120^{\circ} \mathrm{C}$ and $80 \mathrm{~atm} \mathrm{H}_{2}$ using $\mathrm{PtO}_{2}$ as the catalyst. ${ }^{20}$

Finally, following the experimental procedure recently described in a patent, ${ }^{6}(R, S)$-tolterodine was obtained by reductive amination of $3 \mathbf{a}$ after $10 \mathrm{~h}$ at $4 \mathrm{~atm} \mathrm{H}_{2}$ and $48{ }^{\circ} \mathrm{C}$ in methanol, in the presence of $\mathrm{Pd} / \mathrm{C}(5 \%)$ : the yield reached $96 \%$. This latter method is strongly preferable because of the lower cost of the catalyst, the remarkably milder reaction conditions, and the higher chemical yield obtained.

As only the $(+)-(R)$-enantiomer of tolterodine displays the desired pharmacological activity, we devised a way to prepare this chiral drug by enantioselective hydroformylation of olefin 2a and subsequent transformation of the enatiomerically enriched $o x o$-aldehyde obtained. Indeed, the results obtained in the hydroformylation of this substrate catalyzed by rhodium carbonyl complexes modified with phosphorus external ligand did not appear very promising (see Table 1); however, we hoped that a high enantioselectivity could counterbalance a low chemical yield. The catalyst of choice to perform the oxo process was the system $\mathrm{Rh}(\mathrm{CO})_{2} \mathrm{acac}$ $(S, R)$-Binaphos (1:4 molar ratio), thus far the most active catalyst in the enantioselective hydroformylation of various alkenes. ${ }^{21}$ This reaction, carried out on substrate 2a in toluene at $60{ }^{\circ} \mathrm{C}$ and $80 \mathrm{~atm}\left(\mathrm{CO} / \mathrm{H}_{2}=1\right)$ and with a substrate-torhodium molar ratio of 250 to 1 , gave compound $\mathbf{4 a}$ as the only reaction product.

Therefore, we thought to study the behavior towards hydroformylation of substrate $\mathbf{2} \mathbf{b}$, in which the hydroxy group was protected as acetoxy derivative, in the aim of improving the yield of the desired oxo-aldehyde when the oxo process was catalyzed by rhodium-carbonyl complexes modified with external phosphorus ligands.

Compound $\mathbf{2 b}$ was conveniently prepared in $90 \%$ yield by reacting olefin $\mathbf{2 a}$ with acetyl chloride in wet toluene for $2 \mathrm{~h}$ at room temperature in the presence of $\mathrm{NaOH}$ and the phase-transfer catalyst tetrabutylammonium hydrogensulfate. ${ }^{22}$

When 2b was used, the reaction catalyzed by Rh$(\mathrm{CO})_{2}$ acac/ $(S, R)$-Binaphos ${ }^{21,23}$ ran again very sluggishly, and no more than $51 \%$ of conversion was achieved after $168 \mathrm{~h}$ at $60{ }^{\circ} \mathrm{C}$ and $80 \mathrm{~atm}$ (Table 2, entry 1). The chemoselectivity was also very disappointing, about $27 \%$ of olefin hydrogenation product $\mathbf{4 b}$ being detected in the reaction mixture. The chiral nonracemic aldehyde obtained showed an enantiomeric excess of only $8 \%$. This value was determined by aldehyde

(21) Nozaki, K.; Matsuo, T.; Shibahara, F.; Hiyama, T. Adv. Synth. Catal. 2001, 1,343 .

(22) Illi, V. O. Tetrahedron Lett. 1979, 26, 2431.

(23) Nozaki, K.; Ojima, I. Asymmetric Carbonylations. In Catalytic Asymmetric Synthesis; Ojima I. Ed.; Wiley-VCH: New York, 2000, p 429. 

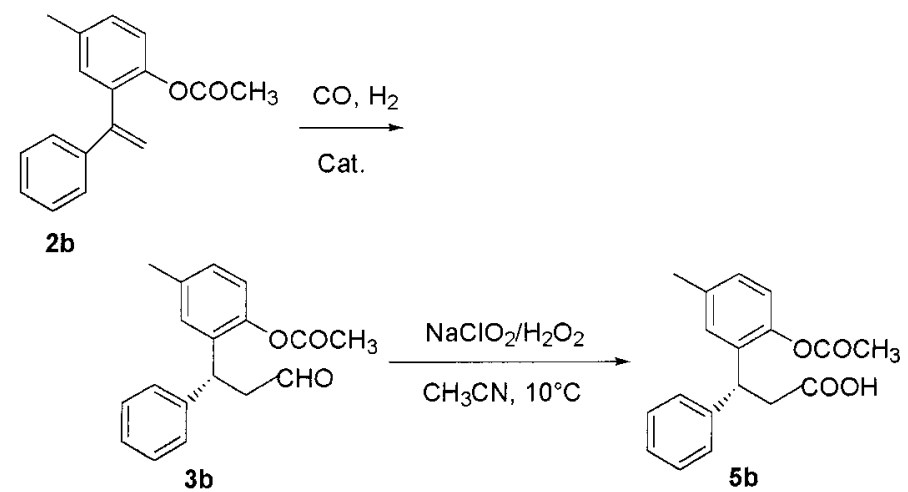

Table 2. Enantioselective rhodium-catalyzed hydroformylation of olefin $2 b^{a}$

\begin{tabular}{|c|c|c|c|c|c|c|c|}
\hline entry & ligand & $\begin{array}{l}\text { substrate/ } \\
\text { catalyst }\end{array}$ & $t(\mathrm{~h})$ & $\begin{array}{l}\text { conv. } \\
(\%)^{b}\end{array}$ & $\begin{array}{c}\text { aldehyde } \\
\text { yield } \\
(\%)^{b}\end{array}$ & $\begin{array}{l}\text { hydrog. } \\
\text { product } \\
(\%)^{b}\end{array}$ & $\begin{array}{l}\text { ee } \\
(\%)^{c}\end{array}$ \\
\hline $1^{d}$ & Binaphos & $250 / 1$ & 168 & 51.4 & 24.7 & 26.7 & 8 \\
\hline 2 & $\mathrm{~L}_{1}$ & $307 / 1$ & 216 & $>99$ & 61.9 & 25.5 & 1 \\
\hline 3 & $\mathrm{~L}_{1}$ & $250 / 1$ & 216 & $>99$ & 37.6 & 59.0 & - \\
\hline 4 & $\mathrm{~L}_{2}$ & $250 / 1$ & 216 & 66.2 & 22.0 & 44.2 & - \\
\hline 5 & $\mathrm{~L}_{3}$ & $250 / 1$ & 144 & 58.7 & 17.6 & 41.1 & - \\
\hline
\end{tabular}

${ }^{a}$ Experimental conditions: cat. $=\mathrm{Rh}(\mathrm{CO})_{2}$ acac; ligand $/ \mathrm{Rh}=4 / 1$ (molar ratio): $P=100 \mathrm{~atm}\left(\mathrm{CO} / \mathrm{H}_{2}=1\right) ; \mathrm{Temp}=100{ }^{\circ} \mathrm{C}$; solvent $=$ toluene. ${ }^{b}$ Determined by GC. ${ }^{b}$ Determined by HPLC (see Experimental Section). ${ }^{c}$ Experiments carried out at $80 \mathrm{~atm}\left(\mathrm{CO} / \mathrm{H}_{2}=1\right)$ and $60{ }^{\circ} \mathrm{C}$.

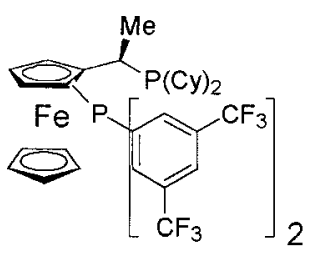

$L_{1}$

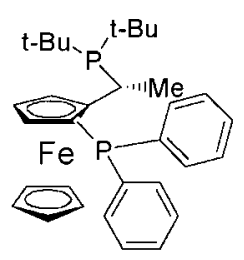

$L_{3}$

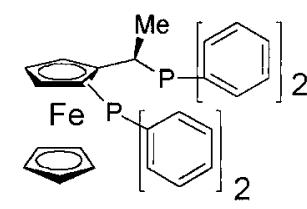

$\mathrm{L}_{2}$

\section{Figure 3.}

$\mathbf{3 b}$ oxidation to the corresponding $\operatorname{acid}^{24} \mathbf{5 b}$ and enantioselective HPLC using the chiral column Chiracel OD (Scheme 2).

Since enantiopure ferrocenylphosphines were seldomly employed as ligands in enantioselective hydroformylation, ${ }^{25,26}$ we carried out some oxo experiments on olefin $\mathbf{2 b}$ using the diphosphines $\mathrm{L}_{1}-\mathrm{L}_{3}$ depicted in Figure 3 to modify the

(24) Dalcanale, E.; Montanari, F. J. Org. Chem. 1986, 51, 567.

(25) Botteghi, C.; Delogu, G.; Marchetti, M.; Paganelli, S.; Sechi, B. J. Mol. Catal. A: Chem. 1999, 143, 311.

(26) Rampf, F. A.; Herrmann, W. A. J. Organomet. Chem. 2000, 601, 138. carbonyl complex $\mathrm{Rh}(\mathrm{CO})_{2}$ acac (Table 2). Only in one case (Table 2, entry 2) we obtained a sufficently high yield (about $62 \%$ ) to isolate from the reaction mixture and to purify the aldehyde $\mathbf{3 b}$; this showed negligible ee.

\section{Conclusions}

In conclusion, we were able to carry out an efficient route to $(R, S)$-tolterodine with an overall yield up to $60 \%$. This preparative scheme, in our opinion, could be convenient for an industrial scale-up; however, all the steps of the preparative route proposed by us and, in particular, that of the hydroformylation step, are under investigation in our laboratory for further improvements. Unfortunately, the asymmetric hydroformylation will hardly be successfully employed for the synthesis of enantiomerically enriched $(+)-(R)$-tolterodine, but other more promising enantioselective catalytic processes are currently under study by us.

\section{Experimental Section}

General Methods. The rhodium complexes $\mathrm{HRh}(\mathrm{CO})$ $\left(\mathrm{PPh}_{3}\right)_{3}{ }^{16}$ and $[\mathrm{Rh}(\mathrm{COD}) \mathrm{Cl}]_{2}{ }^{17}$ were prepared following wellknown procedures. $\mathrm{Rh}(\mathrm{CO})_{2}$ acac and palladium, $5 \mathrm{wt} \%$ on activated carbon, were purchased from Aldrich. Acid $\mathrm{Al}_{2} \mathrm{O}_{3}$ ( $\mathrm{S}, 0.063 \mathrm{~mm}$, Riedel-De Haen AG) was activated by calcination at $550{ }^{\circ} \mathrm{C}$ for $5 \mathrm{~h}$ before use. Phenylacetylene was filtered through a short column of alumina and then distilled at reduced pressure (bp $75^{\circ} \mathrm{C} / 80 \mathrm{mmHg}$ ). Molecular sieves (Aldrich, $4 \AA, 1.6 \mathrm{~nm}$ ) were heated in vacuo at 250 ${ }^{\circ} \mathrm{C}$ for $24 \mathrm{~h} .(S, R)$-Binaphos was prepared following a described procedure. ${ }^{27}$ Merck silica gel 60 (240-400 mesh) was used for column chromatography. NMR spectra were measured for solutions in $\mathrm{CDCl}_{3}$ using a Bruker AC 200 spectrometer operating at $200 \mathrm{MHz}$. Solvents were purified following well-known procedures. ${ }^{28}$

1-[(2-Hydroxy-5-methyl)phenyl]-1-phenylethylene (2a). A mixture of $p$-cresol $(2.16 \mathrm{~g}, 20 \mathrm{mmol})$, phenylacetylene $(2.2 \mathrm{~mL}, 200 \mathrm{mmol})$ and $1 \mathrm{~g}(47 \mathrm{wt} \%)$ of activated acid alumina $\mathrm{S}(0.063 \mathrm{~mm})$ in anhydrous 1,2-dichlorobenzene (12 $\mathrm{mL}$ ) was heated at reflux for $72 \mathrm{~h}$, after which was cooled to room temperature. The alumina was filtered off and washed several times with diisopropyl ether. Removal of the solvent in vacuo left a crude oil, which was purified by

(27) Sakai, N.; Mano, S.; Nozaki, K.; Takaia, H. J. Am. Chem. Soc. 1993, 115, 7033.

(28) Perrin, D.; Armarego, L. F. Purification of Laboratory Chemicals, 3rd ed.; Pergamon Press: Oxford, 1988. 
distillation at reduced pressure $\left(81{ }^{\circ} \mathrm{C} / 32 \mathrm{mmHg}\right)$, so furnishing olefin $\mathbf{2 a}$ as a colorless oil $\left(3.8 \mathrm{~g}, 90 \%\right.$ yield). ${ }^{1} \mathrm{H}$ NMR $\delta 7.41-6.85(\mathrm{~m}, 8 \mathrm{H}), 5.88-5.86(\mathrm{~d}, J=1.21 \mathrm{~Hz}$, $1 \mathrm{H}), 5.44-5.42(\mathrm{~d}, J=1.21 \mathrm{~Hz}, 1 \mathrm{H}), 5.02(\mathrm{~s}, 1 \mathrm{H}), 2.31(\mathrm{~s}$, 3H). MS: m/e $210\left(\mathrm{M}^{+}, 57\right), 209$ (100), 195 (39), 165 (21), 77 (12). Anal. Calcd for $\mathrm{C}_{15} \mathrm{H}_{14} \mathrm{O}$ : C, 85.68; H, 6.71. Found: C, 85.42; H, 6.68 .

1-[(2-Acetoxy-5-methyl)phenyl]-1-phenylethylene (2b). This olefin was prepared in $90 \%$ yield, starting from olefin 2a, according to a described procedure. $.^{22} \mathrm{Bp} 175{ }^{\circ} \mathrm{C} / 0.1$ mmHg. ${ }^{1} \mathrm{H}$ NMR $\delta 7.45-6.85(\mathrm{~m}, 8 \mathrm{H}), 5.88-5.86(\mathrm{~d}, J=$ $1.21 \mathrm{~Hz}, 1 \mathrm{H}), 5.44-5.42(\mathrm{~d}, J=1.21 \mathrm{~Hz}, 1 \mathrm{H}), 2.32(\mathrm{~s}, 3 \mathrm{H})$, 1.80 (s, 3H). MS: m/e $252\left(\mathrm{M}^{+}, 22\right), 237$ (12), 209 (100), 195 (26), 165 (14), 43 (31). Anal. Calcd for $\mathrm{C}_{17} \mathrm{H}_{16} \mathrm{O}_{2}$ : C, 80.93; H, 6.39. Found: C, 80.65; H, 6.37 .

Hydroformylation of 2a. A $150-\mathrm{mL}$ stainless steel reaction vessel was charged under a nitrogen purge with 2 mmol of olefin 2a, $0.008 \mathrm{mmol}$ of rhodium catalyst and 5 $\mathrm{mL}$ of anhydrous toluene. The reactor was then pressurized to $100 \mathrm{~atm}$ with syngas $\left(\mathrm{CO} / \mathrm{H}_{2}=1\right)$ and heated at $80-100$ ${ }^{\circ} \mathrm{C}$ for $24-72 \mathrm{~h}$ (see Table 1). For analytical purposes aldehyde 3a (hemiacetalic form), a white solid, was recovered from the reaction mixture by flash silica gel chromatography (hexane/ether, 80/20). Mp $82.5{ }^{\circ} \mathrm{C} .{ }^{1} \mathrm{H}$ NMR $\delta$ $7.40-6.60(\mathrm{~m}, 8 \mathrm{H}), 5.67(\mathrm{t}, J=3.05,1 \mathrm{H}), 4.36-4.28(\mathrm{~m}$, $1 \mathrm{H}), 2.34-2.20(\mathrm{~m}, 2 \mathrm{H}), 2.16(\mathrm{~s}, 3 \mathrm{H})$. MS: m/e $240\left(\mathrm{M}^{+}\right.$, 100), 222 (66), 221 (72), 195 (57), 145 (70), 115 (25). Anal. Calcd for $\mathrm{C}_{16} \mathrm{H}_{16} \mathrm{O}_{2}$ : C, 80.0; H, 6.71. Found: C, 79.76; H, 6.69 .

Hydroformylation of 2a in Aqueous Biphase Medium. In a Schlenk tube $[\mathrm{Rh}(\mathrm{COD}) \mathrm{Cl}]_{2}(4.0 \mathrm{mg}, 0.008 \mathrm{mmol})$ and TPPTS (27.6 mg, $0.048 \mathrm{mmol}$ ) were dissolved under nitrogen in $\mathrm{H}_{2} \mathrm{O}(2.5 \mathrm{~mL})$; then, a solution of $\mathbf{2 a}(0.5 \mathrm{~g}, 2.0 \mathrm{mmol})$ in toluene $(3 \mathrm{~mL})$ was added. The Schlenk tube containing the two-phase liquid mixture was transferred to a $150-\mathrm{mL}$ stainless steel autoclave under nitrogen, pressurized to 100 atm with syngas $\left(\mathrm{CO} / \mathrm{H}_{2}=1\right)$ and heated at $100{ }^{\circ} \mathrm{C}$ for 48 $\mathrm{h}$ (see Table 1). The reactor was then cooled to room temperature and the residual gases released. The organic phase was separated and dried on $\mathrm{MgSO}_{4}$, and toluene was removed in vacuo; the aldehyde 3a (hemiacetalic form) was recovered and identified as previously described.

Hydroformylation of $\mathbf{2 b}$. A $150-\mathrm{mL}$ stainless steel reaction vessel was charged under a nitrogen purge with 2 mmol of olefin $\mathbf{2 b}, 0.008 \mathrm{mmol}$ of rhodium catalyst, 0.0032 mmol of an external ligand, and $5 \mathrm{~mL}$ of anhydrous toluene. The reactor was then pressurized to $100 \mathrm{~atm}$ with syngas $\left(\mathrm{CO} / \mathrm{H}_{2}=1\right)$ and heated at $80-100{ }^{\circ} \mathrm{C}$ for $24-72 \mathrm{~h}$ (see Table 2). For analytical purposes aldehyde $\mathbf{3 b}$, a pale yellow oil, was recovered from the reaction mixture by flash silica gel chromatography (hexane/ether, 80/20). ${ }^{1} \mathrm{H}$ NMR $\delta 9.73$ (t, $J=1.83,1 \mathrm{H}), 7.45-6.71(\mathrm{~m}, 8 \mathrm{H}), 4.8-4.68$ (t, $J=7.32$, $1 \mathrm{H}), 3.26-3.0(\mathrm{~m}, 2 \mathrm{H}), 2.35(\mathrm{~s}, 3 \mathrm{H}), 1.81(\mathrm{~s}, 3 \mathrm{H}) . \mathrm{MS}: \mathrm{m} / \mathrm{e}$ $282\left(\mathrm{M}^{+}, 6\right), 240$ (15), 222 (100), 196 (10), 145 (19). Anal. Calcd for $\mathrm{C}_{18} \mathrm{H}_{18} \mathrm{O}_{3}$ : C, 76.57; H, 6.42. Found: C, 76.37; H, 6.40.

Determination of the Enantiomeric Excess. The hydroformylation reaction mixture of $\mathbf{2 b}$ catalyzed by $\mathrm{Rh}$ -
$(\mathrm{CO})_{2}$ acac/(S,R)-Binaphos (see Table 2) was oxidized to the corresponding 3-[(2-acetoxy-5-methy)phenyl]-3-phenylpropanoic acid (5b) with $\mathrm{NaClO}_{2}, \mathrm{H}_{2} \mathrm{O}_{2}$, and $\mathrm{NaH}_{2} \mathrm{PO}_{4}$ in $\mathrm{CH}_{3}-$ $\mathrm{CN}$ at $10{ }^{\circ} \mathrm{C} .{ }^{24}$ The enantiomeric excess of $\mathbf{5 b}$ was determined by HPLC analysis using a Chiracel OD $250 \mathrm{~mm}$ $\times 4.6 \mathrm{~mm}$ column $(n$-hexane/2-propanol/formic acid $=90 /$ $10 / 1$, flux $0.5 \mathrm{~mL} / \mathrm{min}$, loop $10 \mu \mathrm{L}$, wavenumber $254 \mathrm{~nm}$ ): $\mathrm{ee}=8 \%$. Compound $\mathbf{5 b}:{ }^{1} \mathrm{H}$ NMR $\delta 9.71(\mathrm{~s}, 1 \mathrm{H}), 7.45-$ $6.71(\mathrm{~m}, 8 \mathrm{H}), 4.8-4.68(\mathrm{~m}, 1 \mathrm{H}), 3.3-2.98(\mathrm{~m}, 2 \mathrm{H}), 2.35$ (s, 3H), 1.80 (s, 3H). MS: m/e $298\left(\mathrm{M}^{+}, 1\right), 280$ (1), 238 (100), 220 (30), 195 (57), 165 (11), 91 (4), 77 (5). Anal. Calcd for $\mathrm{C}_{18} \mathrm{H}_{18} \mathrm{O}_{4}$ : C, 72.47; H, 6.08. Found: C, 72.28; $\mathrm{H}, 6.06$.

$(\boldsymbol{R}, \boldsymbol{S})$-Tolterodine (1). In a $150-\mathrm{mL}$ stainless steel reaction vessel a solution of $\mathbf{3 a}(1 \mathrm{~g}, 4.2 \mathrm{mmol})$ in $5 \mathrm{~mL}$ methanol was slowly added, under a nitrogen purge, to $\mathrm{Pd} / \mathrm{C}(5 \%)(0.11$ $\mathrm{g}, 1.03 \mathrm{mmol})$. Anhydrous $N, N$-diisopropylamine $(0.74 \mathrm{~mL}$, $5.3 \mathrm{mmol}$ ) was added and the reactor pressurized to $3 \mathrm{~atm}$ with $\mathrm{H}_{2}$. After $16 \mathrm{~h}$ at $50{ }^{\circ} \mathrm{C}$ the reactor was cooled to room temperature and the residual gas released. The reaction mixture was filtered, and solvent and excess $\mathrm{HN}\left({ }^{i} \mathrm{Pr}\right)_{2}$ were distilled off in vacuo; the remaining oil was purified by flash chromatography as described by Andersson at al. ${ }^{5}$ Concentration in vacuo yielded $1.32 \mathrm{~g}(96.8 \%$ yield) of $(R, S)$ tolterodine 1 as a colorless oil. ${ }^{1} \mathrm{H}$ NMR $\delta 7.35-6.83(\mathrm{~m}$, $8 \mathrm{H}), 6.55(\mathrm{~s}, 1 \mathrm{H}), 4.53-4.46(\mathrm{~m}, 1 \mathrm{H}), 3.24(\mathrm{q}, J=6.71$, $2 \mathrm{H}), 2.77-2.69(\mathrm{~m}, 2 \mathrm{H}), 2.43-2.32(\mathrm{~m}, 2 \mathrm{H}), 2.13(\mathrm{~s}, 3 \mathrm{H})$, $1.14(\mathrm{~d}, J=6.71,6 \mathrm{H}), 1.09(\mathrm{~d}, J=6.71,6 \mathrm{H}) .{ }^{13} \mathrm{C} \mathrm{NMR}$ $(300 \mathrm{MHz}) \delta 153.11(\mathbf{C H O H}), 144.6(\mathrm{ArCHCH}), 132.3-$ $125.9\left(5 \mathrm{C}, \mathbf{C}_{6} \mathrm{H}_{3}\right), 77.45 .76 .6\left(5 \mathrm{C}, \mathbf{C}_{6} \mathrm{H}_{5}\right), 48.2\left[\mathrm{~N}\left(\mathbf{C H C H}_{3}\right)_{2}\right]$, $42.2\left(\mathrm{NCH}_{2}\right), 39.5[(\mathrm{Ar})(\mathrm{Ph}) \mathrm{CH}], 33.2\left(\mathrm{CHCH}_{2} \mathrm{CH}_{2}\right), 20.9$ $\left(\mathrm{PhCH}_{3}\right), 19.8\left[\mathrm{CH}\left(\mathrm{CH}_{3}\right)_{2}\right], 19.4\left[\mathrm{CH}\left(\mathrm{CH}_{3}\right)_{2}\right]$. MS: m/e 325 $\left(\mathrm{M}^{+}, 8\right), 310$ (13), 114 (100), 100 (5). Anal. Calcd for $\mathrm{C}_{18} \mathrm{H}_{18^{-}}$ $\mathrm{NO}_{3}$ : C, 81.18; H, 9.6; N, 4.3. Found: C, 80.94; H,9.56; N, 4.1

$(R, S)$-Tolterodine (1) by Hydrogenation of Enamine 6. A solution of hemiacetal 3a $(0.5 \mathrm{~g}, 2.08 \mathrm{mmol})$ and anhydrous $N, N$-diisopropylamine $(1.05 \mathrm{~mL}, 7.5 \mathrm{mmol})$ in 2 $\mathrm{mL}$ of anhydrous toluene were slowly stirred, under a nitrogen purge, at $50{ }^{\circ} \mathrm{C}$ in the presence of freshly activated $4 \AA$ molecular sieves $(2 \mathrm{~g})$. After $72 \mathrm{~h}$ the conversion of $\mathbf{3 a}$ to $N, N$-diisopropyl-3-[(2-Hydroxy-5-methyl)phenyl]-3-phenylprop-1-enamine (6) was complete; the molecular sieves were filtered off, and the solvent was evaporated at reduced pressure. Compound $\mathbf{6}$ was characterized by GC/MS; MS: m/e $323\left(\mathrm{M}^{+}, 50\right), 308$ (5), 280 (7), 126(100), 84 (94), 71 (91), 43 (59).

The enamine 6, recovered from the reaction mixture without any further purification, was dissolved in anhydrous toluene $(10 \mathrm{~mL})$ and hydrogenated in the presence of $\mathrm{PtO}_{2}$ (5.0 mg, $0.019 \mathrm{mmol}$ ) at $120{ }^{\circ} \mathrm{C}$ and 80 atm $\mathrm{H}_{2}$ for $24 \mathrm{~h}^{20}$ Tolterodine was obtained in about $90 \%$ yield and characterized as described above.

\section{Acknowledgment}

We are grateful to Dr. Daniele Pegoraro and Dr. Daniela Mazza for the very useful experimental assistance.

Received for review January 28, 2002.

OP020014K 